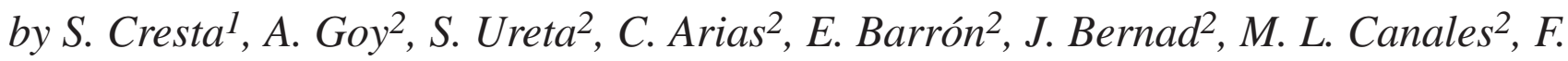
García-Joral $^{2}$, E. García-Romero ${ }^{2}$, P. R. Gialanella ${ }^{2}$, J. J. Gómez ${ }^{2}$, J. A. González ${ }^{2}$, C.

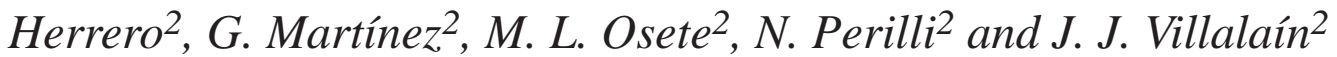

\title{
The Global Boundary Stratotype Section and Point (GSSP) of the Toarcian-Aalenian Boundary (Lower-Middle Jurassic)
}

1. Agenzia regionale Parchi del Lazio, Via Indonesia 33, 00144 Roma, Italy.

2. Departamento de Paleontologia, Universidal Complutense de Madrid, 28048 Madrid, Spain.

\begin{abstract}
The Global Boundary Stratotype Section and Point (GSSP) for the Aalenian Stage, formally defined at the base of bed FZ107 in the Fuentelsaz section, Castilian Branch of the Iberian Range (Spain), has been ratified by the IUGS. Multidisciplinary biostratigraphical data, based on ammonites, brachiopods, ostracods, bivalves, foraminifera, calcareous nannofossils assemblages and palynomorphs, assure worldwide correlations; magnetostratigraphic data increase this correlation power. The position of the boundary coincides with the first occurrence of the ammonite assemblage characterized by Leioceras opalinum and Leioceras lineatum and corresponds with a normal polarity interval correlated with the up-to-date Jurassic magnetic polarity time scale (Gradstein and others, 1994; Ogg, 1995).
\end{abstract}

\section{Introduction}

Multidisciplinary research on the boundary stratotype, developed over many years by the Aalenian Working Group (AWG), was brought to a conclusion in 1998 with the proposition of the Fuentelsaz section (Guadalajara province, Spain), as the best outcrop for defining the Global Boundary Stratotype Section and Point (GSSP) of the Stage. After a positive ballot within the AWG, the resolution was submitted in late 1998 to the International Subcommission on Jurassic Stratigraphy (ISJS) where the overwhelming majority of ISJS Voting Members expressed a positive answer (18 answers (90\%) have been returned: 16 (80\%) answered yes).

\section{The lower boundary of the Aalenian Stage}

The original definition of the Aalenian Stage dates back to 1864 (Ch. Mayer-Eymar, Tableau synchronistique des terrains jurassiques) with geographic references to Aalen on northern side of the Schwäbische Alb (South Germany). The stratotype of the Stage has been discussed by Rieber (1977, 1984), Dietl and Etzold (1977), Ohmert and Zeiss (1988).

On the basis of ammonite fossil assemblages, the European primary standard Aalenian Stage comprises 4 Standard Chronozones, further subdivided into 8 Subzones (Figure 1), which have been tentatively correlated with the standard ones proposed for the Pacific Realm (Hillebrandt and others, 1992, pp. 254-255; Contini and others, 1997, pp. 40). The base of the Stage is therefore taken at the base of the Leioceras opalinum Zone and Subzone. The biochronological correlation power of the European Ammonite Biozones would thus extend beyond the palaeobiogeographical regions where they are usually recognized and applied. Other biostratigraphic zonal schemes are in progress, e.g. for calcareous nannofossils, palynomorphs, brachiopods, ostracods and foraminifera.

The European Lower Aalenian includes the Leioceras opalinum Zone, traditionally used to determine the base of the Stage. For its recognition, in many Jurassic Colloquia (Erlangen, 1984; Lisboa, 1987; Poitiers, 1991; Mendoza, 1994; Vancouver, 1998) and related AWG meeting (Morton, 1991; Cresta and Pavia, 1994), the evolution of the ammonite Subfamilies Grammoceratinae and Leioceratinae has been stated as providing the highest biostratigraphical resolution. In particular the first occurrence of the species of the genus Leioceras, evolved from Pleydellia, has been widely accepted as being the biochronological event which best enables the recognition of the basal boundary of the Aalenian Stage.

On the basis of the more recent literature, the lower boundary of the $L$. opalinum Zone can be assumed to be marked by the first occurrence of the Leioceras opalinum and related species (L. lineatum). Latest forms of the evolutionary transition Pleydellia-Leioceras (Pleydellia misera, P. buckmani) are referable to the lowermost Aalenian (Ohmert, 1996; Goy and others, 1996).

Two sections have been demonstrated to be the best for recording such a biostratigraphic datum: Fuentelsaz at Nuevalos in Spain and Wittnau at Freiburg in southern Germany. Both sections are equally good for documenting the evolutionary lineage within the

\begin{tabular}{|c|c|c|c|c|}
\hline $\begin{array}{l}\text { Age } \\
\text { My }\end{array}$ & $\begin{array}{l}\text { Magnetic } \\
\text { polarity }\end{array}$ & Stages & $\begin{array}{c}\text { European Standard } \\
\text { Ammonite Zones }\end{array}$ & $\begin{array}{l}\text { European Standard } \\
\text { Ammonite Subzones }\end{array}$ \\
\hline \multirow{3}{*}{$\begin{array}{l}176.5 \\
177.2\end{array}$} & & \multicolumn{3}{|c|}{ BAJOCIAN } \\
\hline & & $z$ & Graphoceras concarum & $\begin{array}{l}\text { Graphoceras limitatum } \\
\text { Graphoceras concavum }\end{array}$ \\
\hline & & $\frac{\pi}{z}$ & Brasilia bradfordensis & $\begin{array}{l}\text { Brasilia gigantea } \\
\text { Brasilia bradfordensis }\end{array}$ \\
\hline 178 & & س & Ludwigia murchisonae & $\begin{array}{l}\text { Ludwigia murchisonar } \\
\text { Ludwigia hantgi }\end{array}$ \\
\hline 179.4 & & 6 & Leioceras opalinum & $\begin{array}{l}\text { Leioceras comptum } \\
\text { Leioceras opalimum }\end{array}$ \\
\hline 180 & & \multicolumn{3}{|c|}{ TOARCIAN } \\
\hline
\end{tabular}

Figure 1 Aalenian ammonite standard zones in Europe. 
ammonite Subfamilies Grammoceratinae/Leioceratinae and the early development of Leioceras; both sections are equally good in variability of represented fossil groups. Unfortunately geomagnetic measurements elaborated from the clay pit as well from the borehole Wittnau (Rolf, in Ohmert, 1996) failed to provide a well defined magnetostratigraphic record.

In conclusion, the lower boundary of the Leioceras opalinum Zone in the Fuentelsaz section can be used to define the GSSP for the base of the Aalenian Stage.

\section{Developing the proposal for the GSSP}

From 1991 the AWG members met three times (1991, 1994, 1996) to discuss both the biostratigraphical key defining the Aalenian basal boundary and to develop a common proposal for the Aalenian GSSP according to the Guideline of the ICS (Cowie and others, 1986; Remane and others, 1996). The work concentrated on the Fuentelsaz and Wittnau sections, as no further proposals have been presented.

Portree, Isle of Skye, Scotland, April, 1991 (Morton, 1991) -During lectures, the Wittnau section (Ohmert and others) and Fuentelsaz section (Goy and Ureta) had been proposed as a candidate for GSSP of the Aalenian Stage.

Marrakech, Morocco, May 1994 (Cresta and Pavia, 1994)During lectures both candidate sections were represented with new and up-to-date information useful for the selection of the basal boundary stratotype of the Aalenian Stage.

Nuevalos and Freiburg, September 1996 (Cresta, Aalenews n.6) - On this occasion the candidate sections were visited by the AWG. Two field trip days were devoted to checking and deepening the stratigraphic data collected from Fuentelsaz and Wittnau sections and it is now evident that the information available is the best we could presently obtain. Thirty-two workers attended the meeting and the following countries were represented: Algeria (1), Canada (1), France (3), Germany (6), Great Britain (1), Italy (7), Portugal (1), Spain (10), Switzerland (1). The discussion on GSSP took place in Freiburg on September 25 with the attendance of 26 AWG members and the session actually concentrated on Fuentelsaz and Wittnau sections already discussed twice (Skye 1991, Marrakech 1994).

Following the discussion, the AWG fixed the lowest distinguishable, correlatable Aalenian faunal horizon: at Wittnau Ohmert's (1996, fig. 22) misera horizon (bed 20b) with both Leioceras opalinum and Pleydellia misera plus P. buckmani; at Fuentelsaz an opalinum horizon (bed 107), not so far expressly described as such with $L$. opalinum, L. lineatum and P. buckmani.

The ballot within the Aalenian Working Group, winter 1997 The vote involved the directory af the AWG. Voting papers were mailed to 46 colleagues (Europe 37: France 5, Germany 7, Italy 8, Polonia 1, Spain 8, England 4, Portugal 1, Switzerland 2, Sweden 1; North and South America 8: Argentina 3, USA 2, Canada 3; Africa 2 (Morocco), Asia 2 (Iran 1, Japan 1).

The ballot offered a triple choice: (1) selection of the Wittnau section for Aalenian GSSP; (2) selection of Fuentelsaz section for Aalenian GSSP; (3) abstention meaning that a different section would be proposed. Options (1) and (2) were documented by reports.

By the deadline for the ballot, 31 answers $(70 \%)$ had been returned: 9 (30\%) for Wittnau; 18 (60\%) for Fuentelsaz; 4 (10\%) abstentions. The resolution to define the GSSP of the Aalenian Stage in Fuentelsaz was presented during the meeting of the ISJS (Canada, 1998).

\section{The Fuentelsaz section (Iberian Range, Spain)}

The section is located at $0.5 \mathrm{~km}$ to the $\mathrm{N}$ of Fuentelsaz village, NE of Guadalajara province, Central Sector of the Castilian Branch in the Iberian Range; about $170 \mathrm{~km}$ to the ENE of Madrid and $30 \mathrm{~km}$ to the $\mathrm{N}$ of Molina de Aragón (Figure 2). The topographic map and section coordinates are: sheet $\mathrm{n}^{\circ} 25-18$ (Used), scale 1:50,000, 41 $10^{\circ} 15^{\prime \prime} \mathrm{N}$ and $1^{\circ} 50^{\prime} \mathrm{W}$.
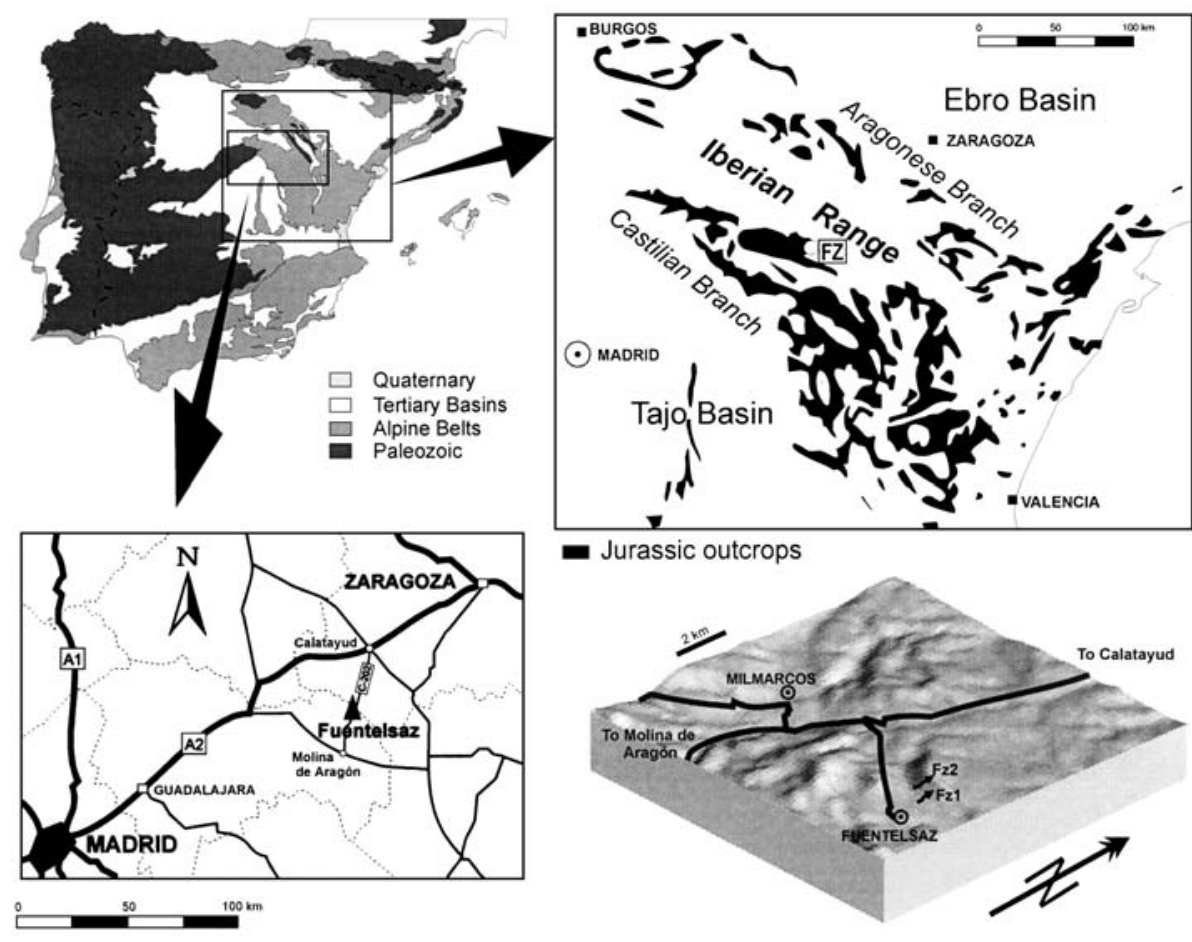

Figure 2 Geological and geographical setting of the Fuentelsaz section. 
The Upper Toarcian and Lower Aalenian show a significant thickness development compared to other areas of the Iberian Range; besides, it contains a well-preserved and complete succession of ammonite assemblages. The lithologies of the P. aalensis and L. opalinum Zones are fairly uniform, consisting of marl-limestone rhythms with ammonites in almost every limestone layer as well as in many of the marl beds. There is also a considerable number of fossils belonging to other varied groups of organisms. Studies have been carried out on benthic elements, that are particularly susceptible to any change at the sediment/water interface (brachiopods, ostracods and foraminifera), on planktonic elements (calcareous nannofossils) and palynomorphs.

The first direct reference to the Aalenian record at Fuentelsaz was made by Goy and Comas-Rengifo (in Portero and others, 1983) in the frame of the preparation of Sheet Used ( $\left.n^{\circ} 25 / 18\right)$ of the Geological Map of Spain 1/50,000. After this date, papers concerning this section are fairly frequent, all of them carried out by the Jurassic Research Group of the Universidad Complutense of Madrid (GarcíaJoral, 1986; Goy and Ureta, 1987, 1990, 1991; García-Joral and others, 1990; Gómez in Gabaldon and others, 1991; Martínez, 1992; Goy and others, 1994, 1996, 1999; Garcl̀a-Joral and Goy, 1995; Herrero and Canales, 1997).

\section{Lithofacies, sequence stratigraphy and sedimentary environments (J.J. Gómez and A. Goy)}

The sediments of the Toarcian-Aalenian transition at Fuentelsaz are composed of marls with interbedded limestones forming an irregular rhytmic alternation (Figures 3 and 4). Marls are dominant in the upper portion of the Pleydellia aalensis Subzone, in the lower part of the P. buckmani Subzone and in the lower part of the L. comptum Subzone. However, carbonates became more important near the Toarcian-Aalenian transition. In general sedimentary structures are absent, except for bioturbation structures and small bioclastic concentrations. The fossil content, in addition to those already mentioned, consists of fine-shelled bivalves, echinoderms and gastropods.

In the Pleydellia aalensis Zone, fossiliferous lime mudstone facies are dominant, whilst wackestone facies are not common. The uppermost rhythm of the Pleydellia aalensis Zone (levels FZ105FZ106) is represented by lime mudstones and marls containing ammonites (Pleydellia, Bredyia), while the lowermost rhythm of the L. opalinum Zone (levels FZ107-FZ108) is constituted by lime mudstone-wackestone facies and marls with ammonites (Leioceras, Bredyia). Bioturbation is present in both cases and the two rhythms are integrated into the same thickening-upwards sequence (Figure 4).

Sediments of the Toarcian-Aalenian transition at Fuentelsaz are organized in shallowing- and deepening-upwards sequences. The uppermost part of the $P$. aalensis Subzone is represented by a shallowing-upward sequence, and the lower portion of the $P$. buckmani Subzone corresponds to a deepening-upwards sequence. The top of this thin deepening sequence is marked by relatively high values in the gamma-ray log. The Toarcian-Aalenian transition is recorded within a shallowing-upwards sequence (levels FZ105-FZ110) that is in turn integrated into a set of shallowing sequences which develop up to the L. opalinum Subzone. A new change in the polarity of the sequences is recorded in level FZ111, where renewed deepening is reflected by the presence of thick intervals of marly sediments, coupled with an increase in the gamma-ray values (Figure 4).

The sediments where the Toarcian-Aalenian transition occurs represent a portion of the Turmiel Formation, defined by Goy and others (1976) in the central portion of the Iberian Range. Sedimentation of this unit at Fuentelsaz took place in one of the fault-controlled subsiding blocks integrated in an extensive marine epeiric carbonate platform that was well connected with the open sea. Hydrodynamic conditions were generally of low energy, with sea bottom located below fair weather wave action, but at a shallow depth (Gómez in Gabaldón et others, 1991; Goy and others, 1995). Full oxygenation of the bottom, which was occasionally affected by currents induced by storms, allowed colonization of the sea bottom by benthic organisms during the Toarcian-Aalenian transition. Recorded sedimentation rates for some of the subzones were relatively high in comparison with surrounding areas, indicating that the stratigraphical record appears to be continuous and one of the most complete known.

\section{Ammonite record and biostratigraphy (A. Goy, S. Ureta and G. Martínez)}

Relatively abundant ammonite assemblages are recorded in the Fuentelsaz section (Figure 4). Complete ammonites with preserved peristome are often found. The assemblages are mainly made up of adult and young specimens of the macro- and microconch forms, especially in the Pleydellia aalensis Zone up to the middle part of the L. opalinum Zone. Ammonites became increasingly scarce from this point onwards, so that it is difficult to determine the type of populations.

The succession of these assemblages has enabled recognition and characterization of all the subzones of the Pleydellia aalensis Zone ( $P$. mactra, $P$. aalensis and $P$. buckmani Subzones) in the Upper Toarcian and of the $L$. opalinum Zone ( $L$. opalinum and $L$. comptum Subzones) in the Lower Aalenian. These assemblages are very similar to those found in other localities of the Iberian Range (Goy, 1974; Goy and Ureta, 1981, 1988, 1990, 1991; Ureta, 1983; Fernández-López, 1985; Ureta and Goy, 1986; Ureta and others, 1999) as well as in other European and Mediterranean basins (Rieber, 1963; Contini, 1969; Mouterde and others, 1971; SuarezVega, 1974; Fernández-López and Suárez-Vega, 1979; Linares 1981; Kalin and Ureta, 1987; Henriques, 1992; Linares and others, 1988; Linares and Sandoval, 1994; Henriques and others, 1996).

Pleydellia aalensis Zone (Upper Toarcian) - This zone is $11 \mathrm{~m}$ thick and 38 levels with ammonites belonging to the Grammoceratinae and Hammatoceratinae have been recognized. Lytoceratina is also present, though only sporadically. This zone is basically characterized by the succession of species of the genus Pleydellia.

The $\boldsymbol{P}$. buckmani Subzone is exceptionally well represented (5m, levels FZ87-106) compared with other areas of the Iberian Range. The first record of the index species Pleydellia buckmani marks the base of this subzone. This species is found throughout the subzone, ranging up into the base of the L. opalinum Subzone, and is particularly abundant in the last $P$. buckmani beds (levels FZ98 to FZ104). Other species of Pleydellia such as $P$. falcifer and $P$. leura are present. This latter species replaces the former and coexists with $P$. buckmani in the upper part of P. buckmani Subzone. Although scarce, Bredyia subinsignis is recorded throughout, and the appearance of a specimen of Lytoceras at level FZ98.2 is particularly noteworthy.

Leioceras opalinum Zone (Lower Aalenian) - The thickness of this zone is at least $23,8 \mathrm{~m}$. The lower limit of the Ludwigia murchisonae Zone could not be identified because the uppermost levels attributed to the $L$. comptum Subzone are eroded and covered with Cretaceous terrigenous sediments. Thirty-four levels have been recognized containing ammonites belonging to the subfamilies Leioceratinae, Hammatoceratinae and Grammoceratinae. This Zone is basically characterized by the succession of the species of the genus Leioceras.

The lowermost part of this zone corresponds to the $\mathbf{L}$. opalinum Subzone $(1,5 \mathrm{~m}$, levels FZ107-111). Its base has been defined with the appearance of the first Leioceras, that coexist with the last species of Pleydellia ( $P$. buckmani and P. leura). Leioceras opalinum and L. lineatum, which presumably belong to the same dimorphic pair, appear simultaneously. The stratigraphic range of 

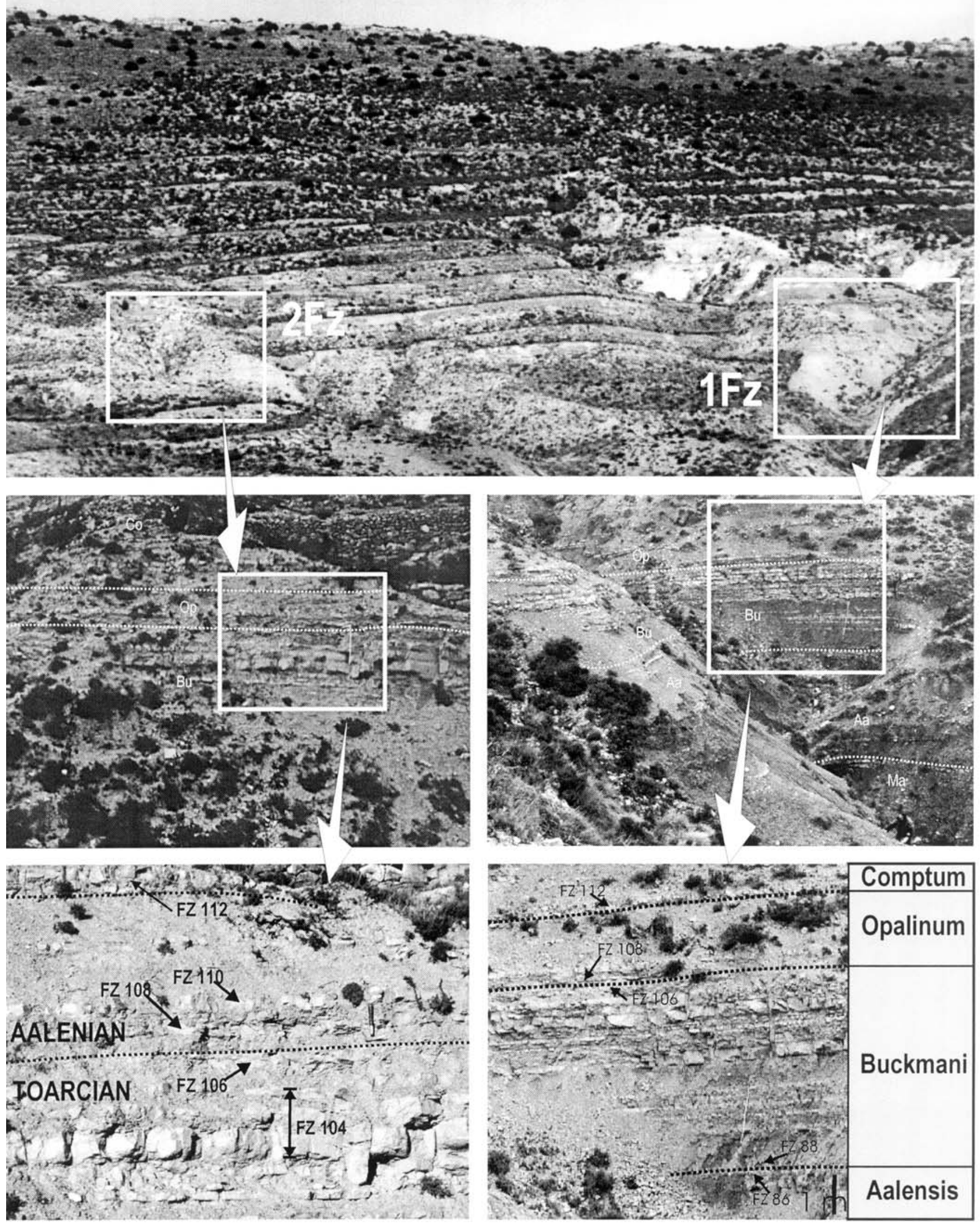

Figure 3 Overall view of the Fuentelsaz section and details of the Toarcian-Aalenian boundary. The Aalenian GSSP is defined at the base of the marly bed FZ107. 

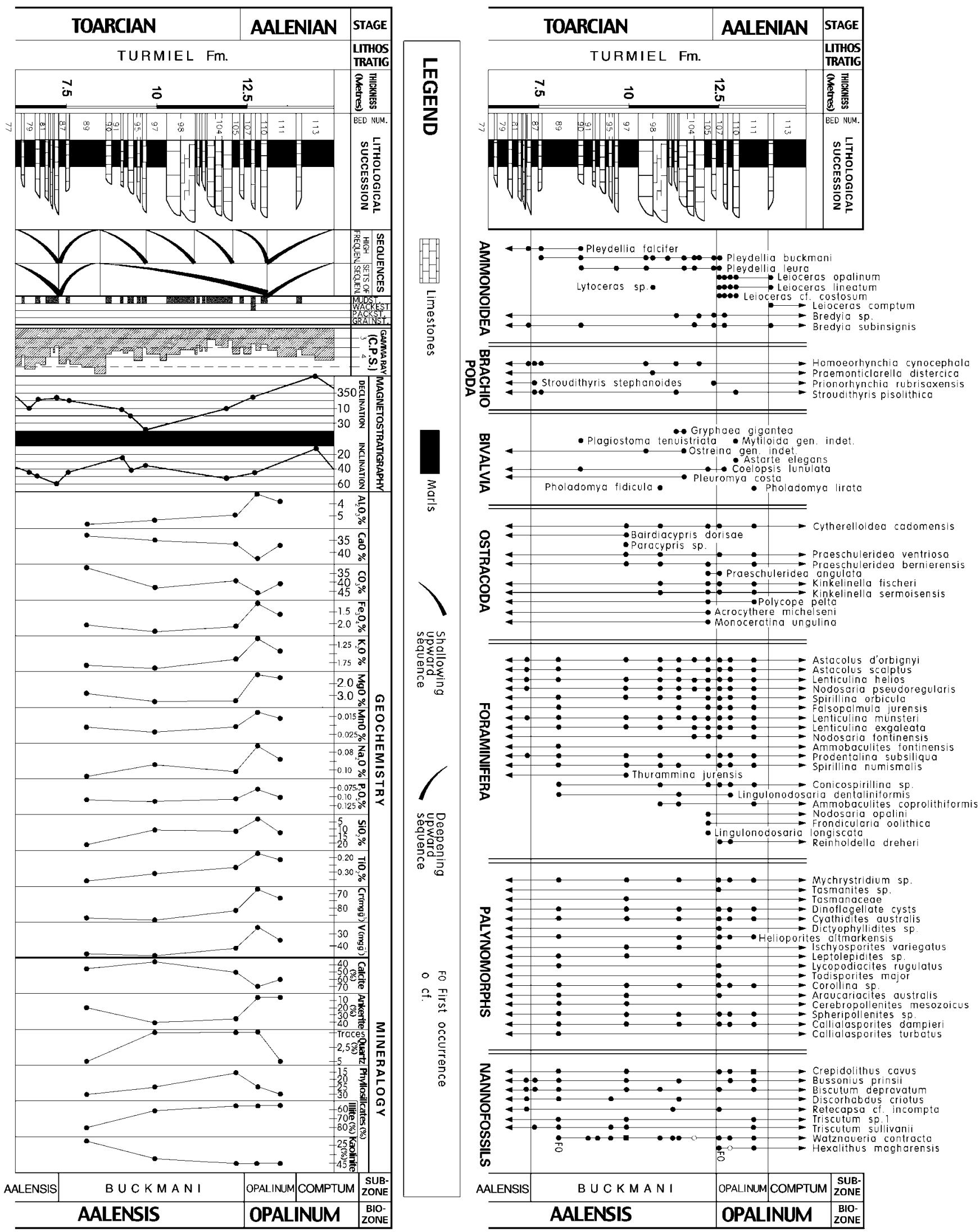

Figure 4 Lithofacies, sequence stratigraphy, magnetostratigraphy, geochemistry, mineralogy and paleontological record of selected taxa within the studied fossil groups in the Toarcian/Aalenian transition at Fuentelsaz section. 
these species extends up to the base of the L. comptum Subzone. Slightly ribbed Leioceras, attributed to L. costosum, appear together with the two latter species, although with a more restricted range. All these forms have been recorded in the same position in other sections of the Iberian Range. As far as the Hammatoceratinae are concerned, Bredyia subinsignis is still present.

Consequently the Toarcian-Aalenian boundary lies immediately above level FZ106, a bed where there is no evidence of early cementation. This boundary is defined by the first record of Leioceras, the first taxon of Graphoceratidae, that coexists with the last Grammoceratinae, genus Pleydellia, at the base of level FZ107. The species of Pleydellia form a phyletic line that links through gradual morphological changes with the phyletic line of the Leioceratinae from the $P$. aalensis Subzone up to the base of the Aalenian. A chronocline from evolute and costulate forms of Pleydellia $(P$. aalensis) to involute and striate forms of Pleydellia ( $P$. leura and $P$. buckmani) and Leioceras (L. opalinum and L. lineatum) can be recognized. However, within this phyletic line Leioceras shows remarkable morphological innovations, that allow its separation from Pleydellia. The change from ovate to tectiform section and the appearance of a wide periumbilical groove that occupies the internal third of the flank, modify significantly the whorl geometry of Leioceras. Besides, a suture line modification with a large number of umbilical lobes takes place together with all those morphological changes.

\section{Brachiopod record (F. García-Joral)}

The brachiopod associations point out (Figure 4) species renewal episode in the $P$. aalensis Subzone in which Homoeorhynchia cynocephala, Praemonticlarella distercica, Stroudithyris pisolithica and possibly more species appear, and another episode of morphological modification of some of these species at the base of the P. buckmani Subzone, at the time of the sedimentation of levels FZ86 and FZ88. Among the terebratulids, this last event (which means the definitive disappearance of the Stroudithyris stephanoides morphotypes) is not very evident due to the gradual nature of the S. stephanoides-S. pisolithica replacement, but among the rhynchonellids this episode gives rise to a notable reduction in size that affects both $H$. cynocephala and P. distercica (García Joral and Goy, 1995). No significant change in the assemblages takes place at the P. buckmani-L. opalinum Subzones transition, although Prionorhynchia rubrisaxensis, a species of wide geographical distribution, appears.

\section{Bivalve record (J. Bernad)}

Several bivalve taxa are recorded in the Pleydellia aalensis Zone but they become scarce from the L. opalinum Subzone onwards (Figure 4). The maximum in abundance and diversity occurs in the $P$. mactra Subzone, where the order Pterioida is mainly represented by the Limacea, Pectinacea and Pteriacea superfamilies. Besides, the suborder Arcoida is restricted to this subzone. In the $P$. aalensis and $P$. buckmani Subzones, the order Pterioida is represented by the suborder Ostreina. The orders Trigonioida, Mytiloida and Pholadomyoida are scarcely represented in the Toarcian/Aalenian transition. Among the bivalve taxa, the most continuous record corresponds to the Veneroida species Coelopis lunulata.

\section{Foraminiferal record (M.L. Canales and C. Herrero)}

Foraminifera do not show major taxonomic or diversity changes in the Toarcian-Aalenian transition (Figure 4). The assemblages are dominated by the suborder Lagenina that can reach $95-100 \%$. An increase in the relative frequency of the Spirillina and Textulariina suborders has been detected at the base of the P. buckmani Subzone and $L$. comptum Subzone, respectively. In the P. mactra Subzone and the base of the $P$. aalensis Subzone Lenticulina toarcense is the dominant-species and from that point onwards Lenticulina helios becomes dominant. Related to the diversity analysis, a significant increase in the Shannon-Wiener and Equitability indices take place at the base of the P. buckmani Subzone. Although the number of specimens recovered decreases, the foraminiferal assemblages are more diversified from this point onwards.

\section{Ostracod record (C. Arias)}

The ostracod assemblages at the Fuentelsaz section (Figure 4) are broadly comparable with those of northwestern Europe in terms of both taxonomic composition (assemblages dominated by species of Praeschuleridea) and stratigraphical ranges. The only major discrepancy is the absence of Aphelocythere kuhni in the Fuentelsaz section, which seems to mark the Toarcian-Aalenian boundary in some other European areas (Knitter, 1984). The ostracod assemblage distributions do show a significant faunal change due to the last occurrence of twelve species throughout the Pleydellia aalensis Zone (Cytherella praecadomensis, C. toarcensis, Praeschuleridea angulata, $P$. gallemannica, Cytheropterina criba, Otocythere callosa). The eight species recorded in the $L$. opalinum Zone extend their ranges from the Pleydellia aalensis Zone (Cytherelloidea cadomensis, Praeschuleridea ventriosa, Kinkelinella fischeri, $K$. sermoisensis, Cytheropterina alafastigata). Thus, the upper ToarcianAalenian boundary is marked by a decrease in the number of ostracod species recorded and by the abundance and preservation of the ostracod assemblages.

\section{Palynomorph record (E. Barrón)}

The palynomorph assemblages consist of spores, pollen grains, acritarchs, dinoflagellate cysts and other organic walled microplankton, such as Tasmanaceae (Figure 4). They are generally well preserved and are similar across the Toarcian-Aalenian boundary. The poorest preserved assemblages appear at the L. comptum Subzone which shows a progressive diversity decrease. The dominant taxon is Spheripollenites sp., possibly related to conifers such as Cupressaceae, Taxodiaceae or Taxaceae. Except for the achritarch Mychrystridium sp., the second best represented taxon, the marine palynomorphs are scarcely represented due to both palaeoenvironmental and taphonomical factors. Among the continental palynomorphs, cheirolepidaceous and araucariaceous pollen grains, as Corollina sp. and Callialasporites dampieri, and trilete spores as Cyathidites australis, Heliosporites altmarkensis and Ischyosporites variegatus, stand out for their relative abundance. The stratigraphical range of $H$. altmarkensis is similar to the one presented in other Jurassic European basins and its last occurrence takes place in the $L$. opalinum Subzone.

\section{Calcareous nannofossil record (N. Perilli)}

Calcareous nannofossil assemblages (Figure 4) show a general decrease in the total abundance, the number of species and the degree of preservation in the interval studied,- although the nannofossil record can be considered as significant and continuous. The main diversity events can be placed at the $P$. mactra- $P$. aalensis boundary and within the $P$. aalensis Subzones, reflected by a distinct decrease in the abundance and preservation of some taxa. Concerning the Toarcian-Aalenian boundary, the most important events are 
the first occurrence of Watznaueria contracta at level FZ89 (base of the P. buckmani Subzone) and the first occurrence of Hexalithus magharensis at level FZ107 (base of the L. opalinum Subzone).

\section{Magnetostratigraphy (P. Gialanella, J.J. Villalaín and M.L. Osete)}

The palaeomagnetic study of the Fuentelsaz section is being currently carried out in an attempt to define its magnetostratigraphic sequence. At the time of writing 118 samples have been collected from $43 \mathrm{~m}$ of the section covering the uppermost Toarcian and the Lower Aalenian (levels FZ22 to FZ203), well represented in this section. The sampling comprised limestones belonging to $D$. pseudoradiosa, P. mactra, P. aalensis, $P$. buckmani, L. opalinum and $L$. comptum Subzones. The results described here are preliminary and are based on a detailed palaeomagnetic study of 46 samples uniformly distributed through the $43 \mathrm{~m}$ investigated (Figure 4).

The samples were drilled and oriented in the field following the standard palaeomagnetic procedure. Magnetic measurements were carried out at the ETH palaeomagnetic laboratory in Zurich. The NRM was measured with a $2 \mathrm{G}$ cryogenic magnetometer. Progressive thermal demagnetization was performed using a Schonsted TSD- 1 furnace in $50^{\circ} \mathrm{C}$ steps up to $350^{\circ} \mathrm{C}$ and in $25^{\circ} \mathrm{C}$ steps thereafter. The low-field magnetic susceptibility was measured after each temperature step in order to monitor any mineralogical change produced by heating. The characteristic components of the NRM were evaluated by least-square fitting of linear segments to orthogonal vector plots during progressive demagnetization. When the last component present showed a very low intensity, the mean direction of the last demagnetization steps was calculated and considered representative.

The initial NRM intensity was generally very low (between $1 \times 10^{-5}$ and $\left.4 \times 10^{-4} \mathrm{~A} / \mathrm{m}\right)$. Thermal and AF demagnetization techniques have been applied to a selection of pilot samples. Thermal treatment was found to be more effective in isolating the different magnetic components present in these rocks. Therefore it was systematically applied to the remaining samples. IRM experiments indicate the presence of only low coercivity minerals in the lower part of the section. In its upper part low coercivity minerals are the more important magnetic phases but also a small amount of high coercivity minerals is present.

Two magnetization components could be identified by thermal cleaning. A low unblocking temperature component, close to the present day field, was generally isolated between $80^{\circ} \mathrm{C}$ and $250^{\circ} \mathrm{C}-$ $300^{\circ} \mathrm{C}$. A high temperature characteristic component could be isolated above $350^{\circ} \mathrm{C}$ and observed until $450^{\circ} \mathrm{C}$. This high temperature component presents normal (mostly) and reversed polarity, and has been considered as the characteristic remanent magnetization $(\mathrm{ChRM})$ of these rocks. In some cases, above $350^{\circ} \mathrm{C}$ the intensity was too low to allow calculation of the direction by least square fitting in the orthogonal plots. In these cases, the characteristic component could only be estimated by calculating the mean direction of the clustering observed in the ortogonal plots. After the $400-450^{\circ} \mathrm{C}$ step of heating, the NRM intensity and bulk susceptibility underwent a sharp increase, indicating that mineralogical changes were induced by heating. The palaeomagnetic directions associated with this increase showed a random distribution. These spurious components mask the characteristic component, impeding an accurate determination of its direction and maximum blocking temperature. Due to these problems many samples had to be rejected.

In spite of the problems in isolating the characteristic component mentioned above, the investigated samples allowed identification of three magnetozones in the studied interval. Two of normal polarity and a reversed magnetozone which extends between the upper part of $P$. mactra Subzone and the lower part of the P. aalensis Subzone. The magnetostratigraphic column is consistent with the composite magnetostratigraphy proposed by Grandstein and others
(1994), but in this study the reversed polarity interval of the $P$. mactra Subzone is better defined biostratigraphycally. The column obtained also correlates essentially with the one obtained by Horner and Heller (1983) at Breggia (Switzerland). Following these authors the Toarcian-Aalenian boundary corresponds to an interval of normal polarity. Below the boundary, they also found a reversed polarity interval, but this one is not calibrated with the biostratigraphical framework.

\section{Geochemistry and mineralogy (E. García-Romero)}

Mineralogical characterization of marl samples collected in the Toarcian-Aalenian transition has been carried out. The identification of minerals has been made through X-ray diffraction by using a d-5000 diffractometre. The chemical analysis has been done in the atomic spectrometry centre of the U.C.M.

Marls consist of $60-80 \%$ of carbonates and $15-45 \%$ of phyllosilicates (Figure 4). The identified carbonates are calcite (35$70 \%$ ) and ankerite (5-40\%). Small amounts of quartz, always below 5\%, and traces of feldspar were also detected. Phyllosilicates are mainly represented by kaolinite and traces of chlorite. No significant variations in the proportion of these minerals are recorded. Only a decrease in the ankerite percentage on account of the calcite content above the level FZ105, which coincides with the ToarcianAalenian boundary (Figure 4) has been recognized. This change is also reflected in the chemical data, where a significant decrease in the $\mathrm{Fe}_{3} \mathrm{O}_{4}$ and $\mathrm{MgO}$ content is recorded in the same levels.

The chemical composition of the bulk sample is indicated in Figure 4. It can be observed that the $\mathrm{CO}_{3}$ and $\mathrm{CaO}$ contents follow the same trend, slightly increasing above the Toarcian-Aalenian boundary, whilst elements associated with the phyllosilicates vary, logically, in a reversed way. $\mathrm{V}$ and $\mathrm{Cr}$ also vary in the same way that phyllosilicates, which suggest that they are associated with those minerals.

\section{Carbon and oxygen isotopes (J. A. González)}

Preliminary data on $\mathrm{C}$ and $\mathrm{O}\left(\delta^{13} \mathrm{C}, \delta^{18} \mathrm{O}\right)$ stable isotopes obtained from Brachiopoda shells are shown. Although rhynchonellids and terebratulids are common, rhynchonellid shells have been mostly used due to the presence of sediment fillings in the punctuated shells of Terebratulids. Rhynchonelloidea goyi (level FZ58) and Homoeorhynchia cynocephala (levels FZ66, 72, 86, 88, base of 98, base of 104, upper part of 104, 128 and 143) shells have been used. Terebratulid shells (Stroudithyris pisolitica, levels FZ110 and 122) were analyzed in those levels with no rhynchonellid record.

Shells of calcitic Brachiopoda have been considered one of the best elements for recognition of the original marine signal of the stable isotopes of C and O (Lowestam, 1961). In order to guarantee an original isotopic signal of the stable isotopes with no alterations, the preservation of the microstructure of the shell has been observed both with MEB and cathodoluminescence. The two methods show the presence of alteration in the primary layer but not in the secondary layer, where the samples have been collected. Samples were picked using a dental microwinch along the anterior-posterior diameter. Organic matter has been removed through heating in vacuo at $400^{\circ} \mathrm{C}$ for 2 hours. Analysis have been performed by the Stable Isotopes Service of Salamanca University. Data are referred to the deviation per thousand $(\delta)$ over the standard PDB. Commited error is \pm $0.04 \delta$ for Carbon and $\pm 0.05 \delta$ for the Oxygen.

$\begin{array}{lllllllllllll}\text { FZ58 } & \text { FZ66 } & \text { FZ72 } & \text { FZ86 } & \text { FZ87 } & \text { FZ88 } & \text { FZ986 } & \text { FZ104b FZ104t FZ110 } & \text { FZ122 } & \text { FZ128 } & \text { FZ143 }\end{array}$ $\begin{array}{llllllllllllll}\delta^{13} \mathrm{C} & 1.30 & 1.56 & 1.40 & 0.76 & 0.52 & 0.91 & 0.43 & 0.70 & 0.65 & 1.55 & -1.43 & 0.96 & 1.30 \\ \delta^{18} \mathrm{O} & -1.85 & -1.74 & -1.48 & -3.04 & -2.34 & -3.07 & -3.86 & -2.53 & -2.85 & -2.20 & -4.09 & -1.99 & -3.13\end{array}$ 
The values of $\delta^{13} \mathrm{C}$ and $\delta^{18} \mathrm{O}$ are summarized in the above table. Only the rhynchonellid samples have been taken into account in the following remarks. The Carbon isotopic average is $1.01 \delta$ and the Oxygen one is $-2.5 \delta$. The rank in the $\mathrm{O}$ isotopes is higher $(2.38 \delta$ values between -1.48 and $-3.86 \delta)$ than the $\mathrm{C}(1.13 \delta$; values between 0.43 and $1.56 \delta$ ). Carbon isotope changes among the different shells are generally small (aproximately of $0.5 \delta$ ). The greatest difference (decrease of $0.6 \delta$ ) is recorded in the samples from levels FZ72 and 86. The uppermost Toarcian sample (level FZ104t) is lighter, in 0.3 $\delta$, than the first sample corresponding to the Aalenian (level FZ128). In relation to oxygen there are higher differences and some cyclycity has been observed. The biggest difference, as in the carbon, is recorded in the samples of the levels FZ72 and 86, with a decrease of $1.56 \delta$.

The differences in the $\mathrm{O}$ isotopes mainly correspond to changes in the temperature and/or salinity of the water masses. The isotopic signal of $\mathrm{C}$ is often related with the tendency to the continentality and changes in the nutrient content. In order to interpret adequately these changes it would be necessary to collect a large number of samples and, in addition, to perform a sampling strategy oriented to prove if isotopic changes are associated with sedimentary sequences, as has been suggested by Wenzel and Joachimski (1996).

\section{Conclusions}

The Global Boundary Stratotype Section and Point (GSSP) for the Aalenian Stage, is formally defined at the base of the bed FZ107 at the Fuentelsaz section (Guadalajara, Spain). In summary, this section fulfills the following requirements:

(1) Global scale correlation by means of ammonites; in particular, with the first occurrence of Leioceras opalinum. The L. opalinum Subzone in the Fuentelsaz section is characterized by the appearance of the first representatives of the genus Leioceras, that coexist with the last representatives of the genus Pleydellia ( $P$. buckmani, and $P$. leura). The species L. opalinum and L. lineatum appear simultaneously. As to Hammatoceratinae, Bredyia subinsignis is still present.

This horizon is perfectly correlatable with the Wittnau section where the base of the L. opalinum biozone is defined by the Pleydellia misera biohorizon, characterized by $L$. opalinum, L. subcostosum, L. subglabrum, L. partitum and the last representative of the genus Pleydellia (P. falcifera, P. misera, P. buckmani).

(2) absence of unconformities in the interval from Upper Toarcian to Lower Aalenian in a section with continuous exposure from $P$. aalensis to L. comptum Subzones.

(3) The sediments corresponding to the uppermost Toarcian and Lower Aalenian are constituted by two main lithologies (total thickness 36 metres), which are organized in elemental sequences composed of marly and calcareous components. These two lithologies irregularly alternate and constitute a rhythmic succession, except for the upper portion of the section (L. comptum Subzone) where limestones are predominant and marly components are very reduced in thickness. The P. aalensis Zone, as well the base of the $L$. opalinum Zone, is characterized by the presence of shallowingupward sequences, except for a small deepening episode localized at the limit between the $P$. aalensis and $P$. buckmani Subzones.

In the central part of the Iberian Range sedimentation took place in a platform or external ramp environment, open and well communicated, under relatively undisturbed conditions. In general the bottom must have been well oxygenated to allow colonization by benthonic organisms, producing the high abundance and diversity of well preserved fossils.

(4) Ammonite, bivalves, brachiopods, ostracods, palinomorphs, foraminifera and calcareous nannofossils have been studied.

The ammonite assemblages are relatively rich in specimens. Generally they are in a good state of preservation (complete specimens with the peristome preserved). This indicates that most of them have accumulated in situ and that redeposition is not common. No evidence of reworking has been found. It has been established that the subsequent assemblages are mainly made up of adult and young specimens of the macro- and microconch forms, especially in the $P$. aalensis Zone and in the lower and middle part of the L. opalinum Zone.

Eleven different species of brachiopods have been distinguished in the P. aalensis and L. opalinum Zones. The stratigraphical distribution of these species basically coincides with what has been observed in other parts of the Iberian Range, although the more marly nature of the sediments in this section in the time interval considered, when compared to the other areas of the basin, probably serves to influence the distributions.

Several bivalves taxa are represented at the beginning of the succession, in Toarcian sediments of the top of the D. pseudoradiosa Zone and the P. mactra Subzone. The maximum of abundance and diversity for the whole section occurs near the middle $P$. mactra Subzone. Diversity decreases slowly in the $P$. aalensis Subzone, but this trend is inverted in the P. buckmani Subzone. In the L. opalinum Zone bivalve taxa are very scarce.

The foraminifera assemblages consist largely of calcareous hyaline species dominated by lenticular forms of the family Vaginulidae. A total of 62 benthic taxa were recognized from the Upper Toarcian to the Lower Aalenian. Agglutinated foraminifera, mainly Saccamminids and Lituolids, were identified in most of the samples. Spirillinids are common throughout all the interval, while Ophtalmidids and Ceratobuliminids are present in small numbers. There is no significant event at the Toarcian-Aalenian boundary.

In the ostracod assemblages of the $P$. aalensis and $L$. opalinum Zones, the species of the genus Praeschuleridea are predominant. Therefore, and for a biostratigraphic point of view, the most important out of those described in our material: $P$. bernierensis, $P$. angulata, $P$. ventriosa, together with Kinkelinella sermoisiensis and $K$. fischeri, are present throughout the interval studied.

A preliminary palynological study on samples from the Toarcian and Aalenian interval has been undertaken. The study has revealed the presence of a well preserved palynological assemblage consisting of spores, pollen grains, acritarch and other organic walled microplankton, such as Tasmanaceae. A total of 18 species has been recognised.

The calcareous nannofossils from the $P$. aalensis to $L$. opalinum Subzones show generally moderately preserved and rare to common assemblages.

(5) No structural complexities or metamorphism of the rocks are present.

(6) Possible correlatable palaeomagnetic results with an inversion from reversed to normal polarity in the $P$. aalensis Subzone.

The magnetostratigraphy of the section is characterized by the existence of a normal polarity interval at the base (N1) which extends between level FZ22 and level FZ54. This is followed by a reversed polarity interval (R1) comprising levels FZ56 to FZ76-86. The reversed interval is overlain by another interval of normal polarity (N2) defined by level FZ88 and FZ163 including, however, several gaps. The reversed magnetozone $\mathrm{R} 1$ extends between the $P$. mactra and $P$. aalensis Subzones and can be correlated with the reversed interval that appears in the Lower and Middle Jurassic magnetostratigraphic column proposed by Gradstein and others (1994).

(7) Easy accessibility of the section well exposed on the cliff at Fuentelsaz.

(8) Classification of the Fuentelsaz area as a Natural Monument is in progress. A formal proposition was presented in November 1999 (Goy and others, 1999).

\section{Acknowledgments}

We would like to thank M.I. Benito, and P. Cozar for the cathodoluminiscence analysis and the ultrathin sections, respectively. This research have been supported by the following projects: PB88-0066, PB91-0383 and PB97-0274 DGICYT, Ministerio de Educación y Cultura (Spain). 


\section{References}

Contini, D., 1969, Les Graphoceratidae du Jura Franc-comtois: Annales Scientifiques Université Besancon, $3^{\text {a }}$ sér. géol, 7, 1-95.

Contini, D., Elmi S., Mouterde R., and Rioult M., 1997, Aalenien, in Cariou E. and Hantzpergue P., eds, Biostratigraphie du Jurassique ouesteuropéen et méditerranéen, 37-40.

Cowie, J. W., Ziegler, W., Boucot, A. J., Basset, M. G., and Remane, J., 1986, Guidelines and statutes of the International Commission on Stratigraphy (ICS): Courier Forschunginstitut Senckenberg, 83, 1-14.

Cresta, S., and Pavia, G, eds, 1994, Proceedings of the 3rd international meeting on Aalenian and Bajocian stratigraphy: Miscellanea del Servizio Geologico d'Italia, 5, 1-321.

Dietl, G., and Etzold, A., 1977, The Aalenian at the Type Locality: Stutgarter Beitrage fur Naturkunde (B)30, 1-13.

Fernandez-Lopez, S., 1985, El Bajociense de la Cordillera Ibérica. Tesis Doctoral. Facultad de Ciencias Geológicas, Universidad Complutense de Madrid. 1-848 (Unpublished Theses).

Fernandez-Lopez, S., and Suarez Vega, L. C., 1979, Estudio bioestratigráfico (Ammonoidea) del Aaleniense y Bajociense en Asturias: Estudios geológicos, 35, 231-239.

Gabaldón, V., and others, 1991, Mapa Geológico de España. Esc. 1:200,000 ( $1^{\text {a }}$ edición). Explicación de la Hoja ${ }^{\circ} 40$ (Daroca). IGME.

García-Joral, F., 1986, Los Braquiópodos del Aaleniense de la Cordillera Ibérica. Tesis Doctoral. Facultad de Ciencias Geológicas, Universidad Complutense de Madrid, 1-326 (Unpublished Theses).

García-Joral, F., and Goy, A., 1995., The associations of Brachiopods from the Toarcian-Aalenian transition in the Fuentelsaz Section (Iberian Range, Spain): Géobios M.S., 17, 223-228.

García-Joral, F.; Goy, A., and Ureta, S., 1990, Las sucesiones de braquiópodos en el tránsito Lías-Dogger en la Cordillera Ibérica: Cuadernos de Geología Ibérica, 14, 55-65.

Goy, A., 1974, El Lías de la mitad Norte de la Rama Castellana de la Cordillera Ibérica. Tesis Doctoral. Facultad de Ciencias Geológicas, Universidad Complutense de Madrid, 3 t., XV + 940 pp. (Unpublished Theses), Sumary: Publicaciones del Departamento de Paleontotología de la Universidad Complutense de Madrid, 14, 1-35.

Goy, A., Gómez, J. J., and Yebenes, A., 1976, El Jurásico de la Rama Castellana de la Cordillera Ibérica (mitad Norte). I Unidades Litoestratigráficas: Estudios geológicos, 32, 391-423.

Goy, A., and Ureta, S., 1981, Bioestratigrafía del Aaleniense en PréjanoMuro de Aguas (Logroño). II Coloquio de Estratigrafía y PaleogeografÌa. del Jur·sico de España (Granada 1979): Cuadernos Geología de la Universidad de Granada, 10, 107-119.

Goy, A., and Ureta, M. S., 1987, Leioceratinae (Ammonitina) del Aaleniense inferior de Fuentelsaz (Cordillera Ibérica, España): Bollettino della Società Paleontologica Italiana, 25 (3), 213-236.

Goy, A., and Ureta, S., 1988, Ammonitina del Toarciense superior en la Sierra Norte de Mallorca (España): Boletin de la Real Sociedad Española de Historia Natural (Geologia), 84(1-2),19-38.

Goy, A., and Ureta, S., 1990, El Aaleniense en la Cordillara Ibérica: Les Cahiers de l'Université Catholique de Lyon. sér. Sciences, 4, 73-87.

Goy, A., and Ureta, S., 1991, The lower boundary of the Aalenian in the Fuentelsaz section (Iberian Range, Spain), in Morton N. ed., Conference on Aalenian and Bajocian Stratigraphy. Isle of Skye, Birkbeck College, Univ. of London, 33-47.

Goy, A., Ureta, S., Arias, C., Canales, M. L., García-Joral, F., Herrero, C., Martínez, G., and Perilli, N., 1994, The Fuentelsaz section (Iberian Range, Spain), a possible Stratotype for the base of the Aalenian Stage: Miscellanea del Servizio Geologico Nazionale, 5, 1-31.

Goy, A., Ureta, S., Arias, C., Bernad, J., Barrón, E., Canales, M.L., GarcíaJoral, F., Gialanella, P. R., Gómez, J. J., Herrero, C., Martínez, G. Osete, M. L., Perilli, N., and Villalaín, J. J., 1996, The Toarcian/Aalenian transition in Fuentelsaz section, in Ureta, S, coord., Fieldtrip Iberian Range Guide-Book ( $1^{\text {st }}$ Toarcian $4^{\text {th }}$ Aalenian Working Groups Meeting), 51-77.

Goy, A., Ureta, S., Arias, C., Barrón, E., Bernad, J., Canales, M. L., GarcíaJoral, F., Gialanella, P.R., Gómez, J.J., Herrero, C., Martínez, G., Osete, M., Perilli, N., and Villalaín, J.J., 1999, The Fuentelsaz section (Guadalajara, Iberian Range, Spain): A possible Global Geosite, in Barettino D. Vallejo M. and Gallego E., eds., Towards the Balanced Management and Conservation of the Geological Heritage in the New Millenium, Madrid (Spain), 60-64.

Gradstein, F. M., Agterberg, F. P., Ogg, J. G., Hardenbol, J., van Veen, P., Thierry, J., and Huang, Z., 1994, A Mesozoic time scale: Journal of Geophysics. Research, 99, 24051-24074.
Henriques, M. H. P., 1992, Biostratigrafia e Paleontologia (Ammonoidea) do Aaleniano em Portugal (Sector Septentrional da Bacia Lusitaniana). Doctoral Thesis. Centro de Geociências da Universidade de Coimbra. Instituto Nacional de Investigacao cientifica, 1-301 (Unpublished Theses)

Henriques, M. H., Linares A., Sandoval J., and Ureta S., 1996, The Aalenian in the Iberia (Betic, Lusitanian and Iberian basins), in Riccardi A.C., ed., Advances in Jurassic Research, Proceedings of $4^{\text {th }}$ International Symposium on Jurassic Stratigraphy, 1-2, 139-150.

Herrero, C., and Canales, M. L., 1997, Diversidad en los foraminíferos del tránsito Toarciense/Aaleniense en la sección de Fuentelsaz (Cordillera Ibérica). Revista Española de Paleontología, 12, 233-242.

Hillebrandt, A. von, Smith, P., Westermann, G. E. G., and Callomon, J. H., 1992, Ammonite zones of the circum-Pacific region, in Westermann G. E. G., ed., The Jurassic of the circum-Pacific: Cambridge University Press, 1-676.

Horner, F., and Heller, F., 1983, Lower Jurassic magnetostratigraphy at the Breggia Gorge (Ticino, Switzerland) and Alpe Turati (Como, Italy): Geophysical Journal of the Royal astronomical Society, 73, 705-718.

Kalin, O., and Ureta, S.,1987, El Lías superior y el Dogger inferior en Gorgo a Cerbara (Apenino Central): Aspectos bioestratigráficos y sedimentológicos: Estudios geológicos, 43, 489-511.

Knitter, H., 1984, Ostracod biostratigraphy of the Upper Toarcian in Southern Germany, in Michelsen, O. and Zeiss, A., eds., International Symposium on Jurassic Stratigraphy Erlangen, 1, 251-258.

Linares, A., 1981, El Jurásico de las Zonas externas de las Cordilleras Béticas. III.5. El Aaleniense en la Zona Subbética, II Coloquio de Estratigrafia y Paleontología del Jurásico de España (Granada, 1979): Cuadernos de Geología de la Universidad de Granada, 10, 107-119.

Linares, A., Ureta, M. S. and Sandoval, J., 1988, Comparison between the Aalenian ammonite association from the Betic and Iberian cordilleras: elements of correlation, in Rocha R.B.and Soares A.F., eds., $2^{\text {nd }}$ International Symposium on Jurassic Stratigraphy, INIC, Lisboa, 193-208

Linares, A., and Sandoval, J., 1994, El Aaleniense de la Cordillera Bética (Sur de España): Análisis bioestratigráfico y caracterización paleobiogeográfica: Revista de la Sociedad geológica de España: 6 (3-4), 177-206.

Lowenstam, H., 1961, Mineralogy, $\mathrm{O}^{18} / \mathrm{O}^{16}$ ratios and strontium and magnesium contents of recent and fossil brachiopods and their bearing on the history of the oceans: Journal of Geology, 69, 241-260.

Mayer-Eymar, C., 1864, Tableau synchronistique des terrains jurassiques, Zurich.

Martínez, G., 1992, Hammatoceratinae (Ammonitina) del Toarciense superior y Aaleniense en la Cordillera Ibérica: Colección Tesis Doctorales no. 374/92, Universidad Complutense de Madrid, 1-331 (Unpublished Thesys).

Morton, N., ed., 1991, Proceedings of Conference on Aalenian and Bajocian Stratigraphy, Isle of Skye, Scotland, 13-20 April, 1990. Birkbeck College, University of London Press, 1-129.

Mouterde, R.; Enay, R., Cariou, E., Contini, D., Elmi, S., Gabilly, J., Mangold, Ch., Mattei, J., Rioult, M., Thierry, J. and Tintant, H., 1971, Les zones du Jurassique en France. Compte Rendus sommaire de la Société géologique de France, 6, 76-102.

Ogg, J. G., 1995, Phanerozoic magnetic polarity time scale: Global Earth Physics, A Handbook of Physics Constants, AGU reference Shelf 1, 240-270.

Ohmert, W., ed., 1996, Die Grenzziehung Unter-/Mitteljura (Toarcium/Aalenium) bei Wittnau und Fuentelsaz. Beispiele interdisziplinarer geowissenschaftlicher Zusammenarbeit. Geologisches Landesamt Baden-Wurttemberg, Informationen, 8, 1-53.

Ohmert, W., and Zeiss, A., 1988, Toarcian/Aalenian. in Rocha, R.B. and Soares, A., eds. Proceedings 2nd Int. Symp. on Jurassic Stratigraphy, Lisboa.

Portero, J., and others 1983, Mapa Geológico de España. Esc. 1:50.000 (2a Serie). Explicación de la Hoja n 464 (Used). IGME.

Remane, J., Bassett, M. G., Cowie, J. W., Gohrbandt, K. H., Lane, R. H., Michelsen, O., and Naiwen W., 1996, Revised guidelines for the establishment of global chronostratigraphic standards by the International Commission on Stratigraphy (ICS). Episodes, 19 (3), 77-81.

Rieber, H., 1963, Ammoniten und Stratigraphie des Braunjura der Schwäbischen Alb. Palaeontographica, (A)122, 1-89.

Rieber, H., 1977, Remarks to the Aalenian of the Swabian Alb. Stuttgarter Beitrage fur Naturkunde, (B)29, 1-5

Rieber, H., 1984, Report of the Aalenian Working Group. Aalenian, present status and open problems. in Michelsen O. and Zeiss A., eds. Proceedings of 1st Int. Symp. on Jurassic Stratigr., 1, 45-54. 
Salvador, A., ed., 1994, International Stratigraphic Guide — a guide to stratigraphic classification, terminology and procedure, 2nd edition. IUGS and the Geological Society of America, 1-214.

Suarez-Vega, L. C.,1974, Estratigrafía del Jurásico en Asturias: Cuadernos de Geologia Ibérica, 3 (1-2), 1-370.

Ureta, M. S., 1985, Bioestratigrafía y Paleontología (Ammonitina) del Aaleniense en el Sector Noroccidental de la Cordillera Ibérica: Colección Tesis Doctorales n ${ }^{\circ} 158 / 85$, Universidad Complutense de Madrid 1-452.

Ureta, M. S., and Goy, A., 1986, El Aaleniense en el área de Talveila (Soria). Bioestratigrafía y evolución sedimentaria:. Estudios geológicos, 42, 331-339.

Ureta, S., Goy, A., Gómez J.J., and Martínez, G., 1999, El límite Jurásico Inferior-Jurásico Medio en la sección de Moyuela (Zaragoza, España): Cuadernos de Geología Ibérica, 25, 59-71.

Wenzel, B., and Joachimski, M. M., 1996, Carbon and oxygen composition of Silurian brachiopods (Gotland/Sweden): palaeoceanographic implications: Palaeogeography, palaeoclimatology, palaeoecology, 122 143-166.

Stefano Cresta was born in Roma, Italy on April 1958. After eighteen years at the Italian Geological Survey, he presently holds a position as Senior Geologist at the Parks Regional Agency of Latium, and teaches Applied Palaeontology at the University of Chieti. He works on land management and on the Conservation of Italian Geological Heritage. His researches have been mainly concentrated on Northern Apennines Jurassic Stratigraphy and on lower mid-Jurassic ammonite biostratigraphy. He has served as secretary (1988-1994) of the Bajocian Working Group and he chaired the Aalenian Working Group for six years and coordinated the activity for the selection of the Aalenian GSSP.
Antonio Goy is Professor of Paleplutense of Madrid. During the last fifteen years he was Head of the Palaeontological Department of this University. Besides he has been Chairman of the Spanish Mesozoic Group and of the Spanish Society of Palaeontology. His research has been mainly focused on Lower Jurassic and Aalenian ammonite taxonomy, biostratigraphy and sequence stratigraphy. From 1987 to 1994 he was Chairman of the Aalenian Working Group of the Subcommission on Jurassic Stratigraphy of the ICS.

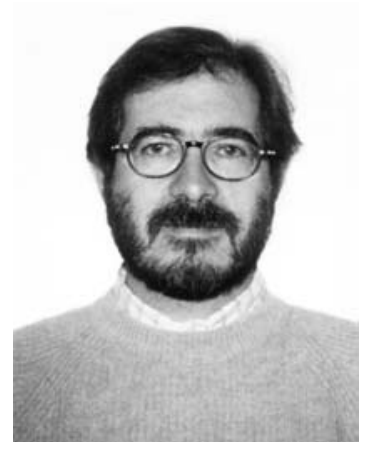

Soledad Ureta is Professor of Palaeontology at the University Complutense of Madrid. She teaches Applied Palaeontology at the Paleontology Department of the Faculty of Geological Sciences. Her research has concentrated on ammonite taxonomy, biostratigraphy, biocronology and taphonomy of the Upper Toarcian and Aalenontology at the University Com-

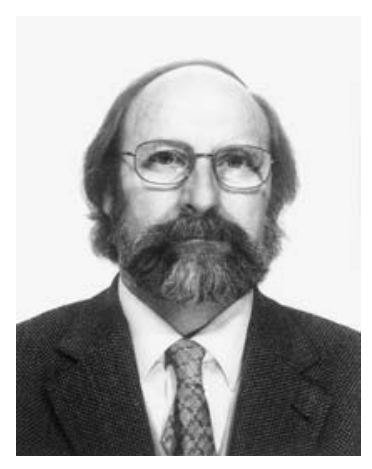
ian, and more recently, she coordinates a project on Integrated Stratigraphy of the Lower-Middle Jurassic Boundary. She has been member of the Aalenian Working Group since 1987.

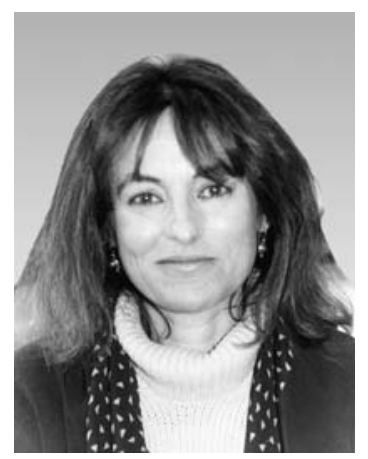

\title{
CALL FOR PAPERS
}

Episodes is the quarterly science and news journal of the International Union of Geological Sciences (IUGS). It focuses on the publication of results of scientific research and other information addressing issues of interest to the global earth-science community. Special emphasis is given to topics involving geological aspects of population growth and economic development and their resulting impacts on or implications for society. As the principal publication of the IUGS, Episodes also carries information about IUGS scientific programs and activities to the extent necessary to communicate effectively with the worldwide IUGS constituency.

Contributions of the following types of manuscripts are here solicited:

- review papers

- scientific articles

- conference reports

- news and views

- letters to editor

- book reviews

- information on training courses (especially those geared to participants from developing countries)

- noteworthy new publications, including national or regional geologic maps

Episodes also invites photos or other images for the front cover. Photos must be of high technical quality and tell an interesting geological story. A color transparency and one color print (at least $9 \mathrm{~cm} \times 12.6 \mathrm{~cm}$ ) are required for submission, which should be supplemented with a short explanatory paragraph (no more than 100 words).

Please address all contributions to:

\author{
The Editor \\ Episodes \\ P. O. Box 823, 26 Baiwanzhuang Road \\ 100037 Beijing, CHINA \\ Tel: +86-10-68320827; +86-10-68329084 \\ Fax: +86-10-68328928; \\ E-mail: episodes@public2.bta.net.cn
}

